\title{
Differences in Perceived Risk between Apparel Buyers and Non-buyers in Online Context
}

\author{
MOUDI ALMOUSA \\ King Saud University, Riyadh, Saudi Arabia \\ Email: almousa@ksu.edu.sa \\ Tel: +96618058041
}

\begin{abstract}
Drawing on marketing and psychometric paradigms, the purpose of this study was to investigate the differences in risk perception in online shopping between apparel and non-apparel internet buyers among Saudi consumers. A web-based survey was conducted to measure consumers' perception of the six types of risk associated with both, apparel and non-apparel online shopping. Three hundred and nineteen responses were collected. Results showed significant differences in two risk dimensions between apparel internet buyers and non-apparel or (other products) buyers. Specifically, psychological and privacy risks are perceived higher for non-apparel buyers. Moreover, non-apparel internet buyers have higher aggregate degree of perceived risk towards apparel internet shopping.
\end{abstract}

Keywords: Consumer Behavior, Apparel, Risk Dimensions, Internet Shopping, Risk Perception.

\section{Introduction}

During the past two decades, the internet has created a new marketing channel with expanded opportunities (Hamann 2000). Internet shopping is considered one the most growing forms of shopping (Levy \&Weitz 2001; Shim, Eastlick, and Lotz 2000). Despite the economic downturn during 2008, Electronic commerce (e-commerce) has continued to experience exponential growth. According to Forrester report, the forecasts online retail sales in the U.S. will be nearly $\$ 250$ billion, up from $\$ 155$ billion in 2009. During 2016, online retail sales were up 11 percent, compared to 2.5 percent for all retail sales. The internet has enabled both, retailers and consumers to interact in a new retail medium, where internet vendors can sell products and services and consumers can search products and buy goods and services. However, consumers have shown reluctance to engage in or finish an online transaction due to risk perceived during online shopping (Jarvenpaa and Tractinsky 1999; and Pavlou 2001). Previous literature indicated that perceived risk in internet shopping negatively influence consumer behavior during online shopping (Park, Lee, and Ahn 2004). The marketing literature concluded that perceived risk influences consumer behavior (Conchar et al. 2004; and Salisbury, Pearson, Pearson, and Miller 2001).

Since the introduction of the internet in Saudi Arabia in 1998, there has been a tremendous increase in internet users; where there were one million users during 2001 and around 30 million users in the beginning of 2018 with 35\% annual growth and 38\% usage among the population (CITC 2018). According to the latest World Internet User Statistics report, Saudi Arabia ranked second after Iran among Middle Eastern countries in internet usage. The Saudi Arabian market is considered the largest retail market in the Middle East. According to Business Monitor International report (2016), the forecast average annual private consumption growth in Saudi Arabia is 7.9\% between 2014 and 2018. The purpose of this study is to investigate the differences in risk perception in online shopping between apparel and non-apparel products 
among Saudi consumers. Specifically, the perceived risk is investigated as a multidimensional concept, where investigating it as a one-dimensional perspective is the predominant in internet literature. It helps in explaining not only do consumers face risk during online shopping, but explains the kind of risks consumers face when shopping online. This study investigates differences in perceived risk from a multidimensional perspective between apparel and non-apparel internet shoppers. Six hypothesis where formulated to test differences in perceived risk on online shopping from a multidimensional perspective between the two groups.

This paper is organized as follows. The next section presents literature review for related variables and the theoretical background of Theory of Risk Perception investigating Saudi Arabian consumers' perceived risk towards online apparel shopping. The second section provides a foundation and framework of the study. The third section describes the research methodology. An analysis of results follows in the fourth section. The final section provides discussion of research results as-well-as implications and limitations of the study.

\section{Background Literature}

\section{Theoretical Framework}

The theory of perceived risk is used as a framework for this study. The concept of risk perception was first introduced in the consumer behavior literature by Bauer (1960). Bauer (1967) considered risk perception as a combination of uncertainty with the possibility of serious outcomes. Perceived risk is a compensation of two factors, uncertainty with the possibility of loss as a consequence of certain behavior and the importance attributed to that loss (kogan and Wallach 1964; Cox, 1967). It has been defined as "the nature and amount of risk perceived by a consumer in contemplating a particular purchase decision" (Cox and Rich 1664, p. $33)$.

\section{Perceived Risk}

The popularity of internet shopping has stimulated widespread research aimed at attracting and retaining consumers from either a consumer- or a technology-oriented view (Jarvenpaa and Todd 1997). However, many scholars have argued that perceived risk in internet shopping negatively influence consumer behavior during online shopping (Park, Lee, and Ahn 2004) and intention to shop online (Salisbury, Pearson, Pearson, and Miller 2001; Pavlou 2003; and Shim et al. 2000). Consumers' attitude towards purchasing sensory products (e. g. apparel) through the internet is not as positive as their attitude towards purchasing other products such as books or computer software. Consumers are used to judge and evaluate apparel products at the point of sale, which is inside the store (Sproles and Burns 1994; and Brown and Rice 1998). On the online context, tangible product attributes of search products become intangible, as in the case of apparel attributes such as fit and fabric texture. The lack of ability to physically evaluate apparel products through the internet creates a significant risk for apparel internet shoppers.

Shopping has long been recognized as a risky activity especially in the context of online shopping. Since the introduction of perceived risk in consumer behavior literature, several studies have been conducted to explain this concept and its impact on consumer behavior. Many scholars have argued that perceived risk in e-commerce negatively influence attitude towards internet shopping (Jarvenpaa and Todd 1997; O'Cass and Fenech 2003; Fenech and O'Cass 2001; shih 2004), intention to shop through the internet (Salisbury, Pearson, Pearson, and Miller 2001; Liao and Cheung 2001; Gefen, 2003; and Pavlou 2003) and internet shopping behavior (Park, et. al., 2004). Hence, five types of risks while making purchase decision have been identified; performance, financial, time, social, and psychological risks. Later research explaining perceived risk in internet shopping has identified an additional risk dimension including privacy risk, which includes both, personal and credit card information. Based on perceived risk and e-commerce literature, the following research hypotheses were proposed: 
H1a: Internet apparel shoppers will perceive performance risk towards apparel online shopping differently than non-apparel shoppers.

H1b: Internet apparel shoppers will perceive financial risk towards apparel online shopping differently than non-apparel shoppers.

H1c: Internet apparel shoppers will perceive psychological risk towards apparel online shopping differently than non-apparel shoppers.

H1d: Internet apparel shoppers will perceive social risk towards apparel online shopping differently than non-apparel shoppers.

H1e: Internet apparel shoppers will perceive time risk towards apparel online shopping differently than non-apparel shoppers.

H1f: Internet apparel shoppers will perceive privacy risk towards apparel online shopping differently than non-apparel shoppers.

\section{Apparel Internet Shopping and Perceived Risk}

Consumers in developed countries have a history of purchasing apparel through the mail, which can be converted into an online product category. In the contrary, as a developing country, consumers in Saudi Arabia have no history in buying products through the mail, where this ancient culture are used to face-toface transactions. Moreover, until recently, Saudi Arabia lacked a standardized address system for homes and businesses in the country. Starting 2005, the country developed a state of the art postal address system, where each residence and business needs to activate in order to receive mail. During 2010, the Saudi postal system serving five million locations in 40 cities and serving 80 per cent of the Saudi population (WAS 2010). The Saudi Postal Service Project (Wasil) has been instrumental in modernizing the communication sector in the country. Due to the increased reliability of the postal service, businesses in Saudi Arabia are starting to adopt e-commerce business models and sell their products online. Moreover, consumers are able to shop across-borders even if the internet vendor does not provide international shipping service through (Wasil International), where the Saudi mail service provides a shipping address for consumers to use when shopping in the U. S., Europe, China, and Australia.

Consumers' attitude towards purchasing sensory products (e. g. apparel) through the internet is not as positive as their attitude towards purchasing other products such as books or computer software (Shim et. al. 2000). Consumers are used to judge and evaluate apparel products at the point of sale, which is inside the store (Sproles and Burns 1994; and Brown and Rice 1998). On the online context, tangible product attributes of search products become intangible, as in the case of apparel attributes such as fit and fabric texture. The lack of ability to physically evaluate apparel products through the internet creates a significant risk for apparel internet shoppers. In the contrary, internet shopping provides consumers with easy access to other product information such as product specifications, consumers' satisfaction ratings, and customer reviews. Keen, Wetzels, Deruyterd, and Feinburg (2004) argues that although scholars had intensively researched the consumer decision- making process in retail stores, more research is needed to identify the drivers to use the internet as a shopping channel. According to this empirical evidence, the following hypothesis was advanced:

H2: Apparel internet buyers will show a lower level of overall perceived risk towards apparel internet shopping than will non-apparel internet buyers.

\section{Methodology}

A web-based survey was conducted to measure differences in consumers' perceptions of the six types of risk associated with apparel and non-apparel online shopping. The link for the questionnaire was sent to a random sample consisting of 3,000 Saudi consumers through SMS and e-mail messages. The questionnaire was posted online for a period of four weeks. Three hundred and twenty responses were collected. 


\section{Questionnaire Development}

For a dependent variable in this study, a multi item scale was constructed to measure differences in risk perception in online shopping between apparel and non-apparel products among Saudi consumers. Survey items include two sections; demographic information and internet usage and six constructs of perceived risk. Demographic variables (gender, age, and income) were measured using ordinal scales. Other variables that were measured include internet usage. Respondents were asked questions regarding internet usage patterns and online shopping experience such as, experience in internet usage, product categories bought through the internet, and previous internet purchase (all measured using ordinal scale). The second section includes items measuring risk perception, which was measured in terms of eighteen item scale measuring six perceived risk constructs including; financial, social, performance, time, psychological, and privacy risks, which was adopted from Garner (1986), Jarvenpaa and Todd (1997), and Featherman and Pavlou (2003). Responses for the section were obtained in a seven-point Likert scale, were $(1=$ totally disagree $)$ and $(7=$ totally agree $)$.

\section{Sample Description}

A total of 319 responses were obtained which were all usable. With the use of JavaScript, respondents were alerted about incomplete responses, if any, when he or she clicks on the submit button. From the sample obtained, 202 were non-apparel internet buyers, and 117 were apparel internet buyers. Table 1 shows the social-demographic profile of the study sample.

Table1. Demographic profile of the study sample.

\begin{tabular}{|lcccc|}
\hline & Non-apparel buyers & \multicolumn{3}{c|}{ Apparel buyers } \\
\hline & $(\mathrm{N}, 202)$ & $\%$ & $(\mathrm{~N}, 117)$ & $\%$ \\
\hline Gender & & & & \\
Male & 94 & 29.4 & 52 & 16.3 \\
Female & 108 & 33.8 & 65 & 20.3 \\
Age & & & & \\
$18-25$ & 106 & 33.2 & 65 & 20.3 \\
$26-35$ & 55 & 17.2 & 24 & 17.2 \\
Over 35 & 41 & 12.8 & 19 & 5.9 \\
Internet usage experience & & & & \\
Less than one year & 4 & 1.2 & 4 & 1.2 \\
I-2 years & 17 & 5.3 & 8 & 2.5 \\
$3-4$ years & 42 & 13.1 & 26 & 8.1 \\
$5-7$ years & 63 & 19.7 & 35 & 10.9 \\
More than 7 years & 69 & 21.6 & 33 & 10.3 \\
Monthly Household Income & & & & \\
Under $\$ 10,000$ & 5 & 1.5 & 2 & .6 \\
$\$ 10,001$ to less than $\$ 20,000$ & 12 & 3.7 & 5 & 1.5 \\
\$20,000 to less than 35,000 & 8 & 2.5 & 4 & 1.2 \\
\$35,000 to less than $\$ 50,000$ & 11 & 3.4 & 4 & 1.2 \\
\$50,000 to less than $\$ 75,000$ & 13 & 4 & 16 & 5 \\
\$75,000 to less than $\$ 100,000$ & 28 & 8.7 & 10 & 3.1 \\
$\$ 100,000$ or more & 130 & 40.7 & 71 & 22.2 \\
\hline
\end{tabular}

\section{Results}

A pilot study was conducted with twenty college students to test instrument validity. To test for instrument reliability, Cronbach alpha was conduct for the measured constructs Table 2 shows the descriptive statistics for the constructs and the reliability of study measurements. To test the research hypotheses, an independent sample t-test was preformed to test hypothesis 1 (a, b, c, d, e, f) and hypothesis 2 . In order to examine the similarities and differences between the two groups, the mean scores of each of the six 
dimensions of perceived risk were compared. Results of the independent sample t-test indicated that there were significant differences between apparel and non-apparel internet buyers in two risk dimensions; psychological and privacy risks (table 3). Non-apparel internet buyers perceive more psychological and privacy risk than apparel internet buyers.

Table 2. Descriptive statistics and reliability test

\begin{tabular}{|cccc|}
\hline Construct & Mean & S.D. & Alpha \\
\hline Financial Risk & 4.81 & 1.76 & .797 \\
Performance risk & 4.87 & 1.76 & .852 \\
Social risk & 3.45 & 1.90 & .924 \\
Time risk & 4.19 & 1.49 & .733 \\
Psychological risk & 4.58 & 1.83 & .862 \\
Privacy risk & 4.43 & 1.85 & .805 \\
\hline
\end{tabular}

Although the overall risk mean is higher for non-apparel internet buyers $(\mathrm{M}=3.95, \mathrm{SD}=1.34)$ and apparel internet buyers $(\mathrm{M}=3.4, \mathrm{SD}=1.32)$, the mean difference between the two groups is not statistically significant at .05 level. Thus, H2 was not supported.

Table 3. Mean comparison between internet apparel buyers and non-buyers

\begin{tabular}{|lcccccc|}
\hline & \multicolumn{2}{c}{$\begin{array}{c}\text { Apparel buyers } \\
(\mathrm{N}, \mathrm{N}, \mathrm{31})\end{array}$} \\
\hline Construct & $M$ & $S D$ & $M$ & $S D$ & $t$ & Sig \\
\hline Financial Risk & 4.24 & 1.60 & 3.67 & 1.66 & 1.61 & .11 \\
Performance risk & 4.56 & 1.93 & 4.26 & 1.54 & .75 & .45 \\
Social risk & 2.95 & 1.95 & 2.47 & 1.90 & .52 & .60 \\
Time risk & 4.01 & 1.46 & 3.44 & 1.47 & 1.82 & .07 \\
Psychological risk & 4.14 & 1.84 & 3.27 & 1.75 & 2.22 & $.02 *$ \\
Privacy risk & 3.81 & 1.81 & 3.00 & 1.61 & 2.15 & $.03 *$ \\
Overall risk & 3.95 & 1.34 & 3.4 & 1.32 & 1.93 & .056 \\
\hline
\end{tabular}

* t-test results for the differences between the two groups are significant at the 0.05 level.

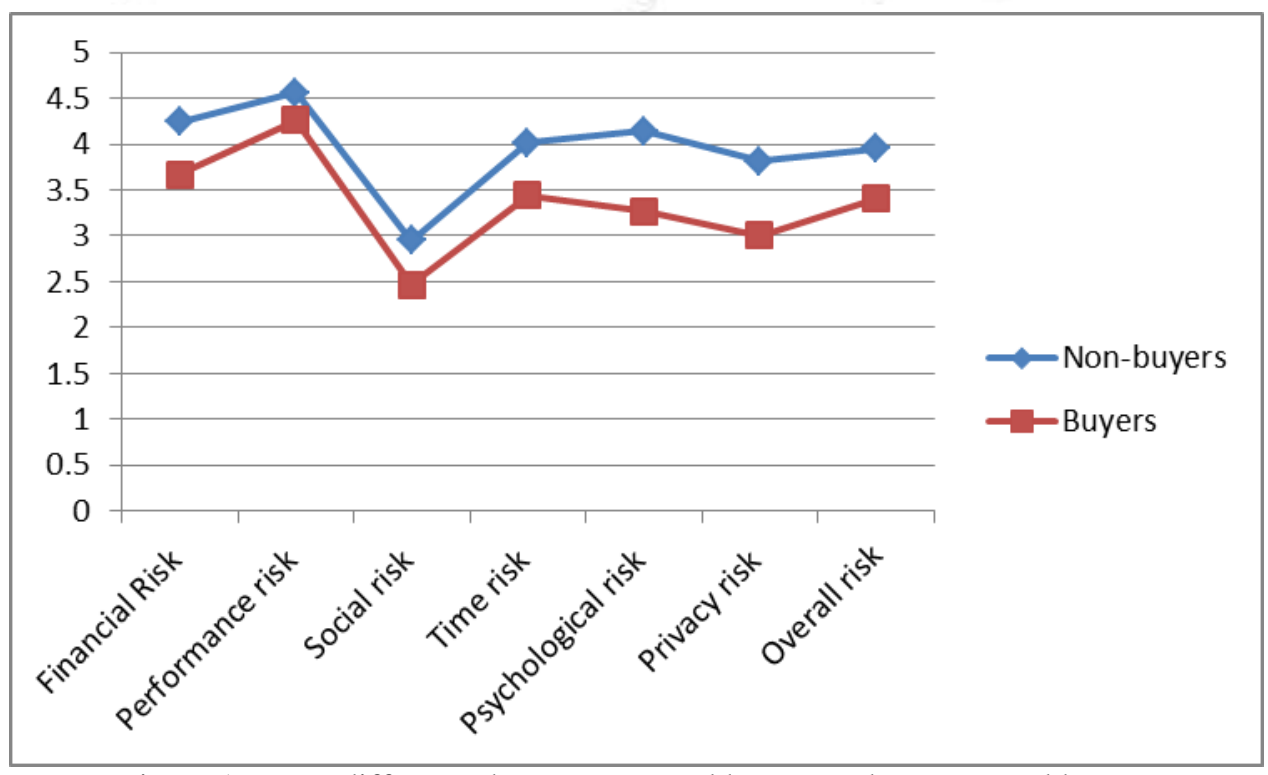

Figure 1. Mean difference between apparel buyers and non-apparel buyers 


\section{Discussion}

This study showed significant differences in two dimensions of perceived risk on online shopping between apparel internet buyers and non-apparel internet buyers. Consumers with no previous experience with apparel online shopping might undergo more psychological and mental stress, which may be caused by the feeling of tension or uneasiness while shopping for apparel products online. Moreover, consumers consider social psychological aspects of clothing consciously when they shop online for apparel products. Findings of the study also indicated that non-apparel shoppers perceive more privacy risk when considering shopping for apparel products online, which might be due to their unfamiliarity with online apparel vendors. Consumers with previous experience in online shopping may have the ability to verify the trustworthiness and believability of the online vendors before making their transaction.

In accordance with the results obtained, psychological and privacy risk items are more related to the evaluation of the shopping channel itself rather than the product. Therefore, non-apparel internet buyers seemed to be more concerned about the possible loss of their peace of mind and money when considering shopping for clothing through apparel internet vendors. It appears that shopping online for apparel products is still a risky proposition even for consumers who already have previous experience on buying other product categories through the internet. In order to reduce tension and fear of financial loss, apparel internet vendors should try to attract potential consumers, especially non-apparel internet shoppers, by emphasizing security measures implemented by the seller. Consumers can judge the security of an online vendor through security features implemented in the seller's website such as security policy and security disclaimer aswell-as protection mechanisms such as authentication and encryption. Consequently, consumers then can recognize the vendor's intention to secure consumes online transactions (Chellappa and Pavlou 2002). Although consumers with previous experience with none apparel internet shopping perceive more risk when considering shopping online for apparel products than consumers who already bought apparel products online, the mean difference was not statistically significant.

Results of this study confirmed that the psychological and privacy characteristics of risk differ significantly between non-apparel internet buyers and apparel internet buyers. It appears that non-apparel internet buyers are more concerned about potential financial consequences, involuntary exposure, and uneasiness when considering shopping for apparel products on the internet. The results obtained have important implications for marketers. Results showed that from the sample obtained, a little over 32 percent were internet buyers and from those, only 31.6 percent were apparel buyers. Apparel internet marketers can attract potential consumers; either non-apparel buyers or other internet users through emphasizing security measures on their websites, which in turn can reduce the anxiety of new consumers. By enforcing trust in apparel sopping virtual transactions, can form a fundamental competitive advantage.

This study has some limitations that need to be considered. Although the study analyzed risk perception in using the internet as a shopping channel using one product category, findings of this study are limited by the measures and sample used. The use of self-reported measures of risk variables might initiate measurement error into the data. Moreover, the use of a convenient sampling method and only consumers who chose to respond were included had limited the generalizability of the study findings.

\section{References}

Bauer, R. A. (1960). Consumer behavior as risk taking. in Cox, D. (Ed.), Risk taking and information handling in consumer behavior, Harvard University Press, Cambridge, MA, pp. 389-398.

Bauer, R., (1967). Consumer behavior as risk taking. In: Cox, D. (Ed.), Risk taking and information handling in consumer behavior. Harvard University Press, Cambridge, MA, pp. 287-293.

Brown, P \& Rice, J. (1998). Ready-to-wear apparel analysis. 2nd ed. Merrill-Prentice-Hall. New Jersey.

Chellappa, R. K. and Pavlou, P. A., (2002). Consumer trust in electronic commerce transactions. Logistics Information Management, 15, (5/6), 358-368. 
CITC, (2018). Communications and information Technology Commission

Conchar, M. P., Zinkhan, G. M., Peters, C. and Olavarrieta, S. (2004). An integrated framework for the conceptualization of consumers' perceived risk processing. Journal of the Academy of Marketing Science, 32, (4), 418-436.

Cox, D. F. and Rich, S. U. (1967). Perceived Risk and Consumer Decision Making: The Case of Telephone Shopping. In Donald F. Cox (eds.), Risk Taking and Information Handling in Consumer Behavior, Boston, MA: Harvard University Press, 487-506.

Cox, D. F., \& Rich, S. U. 1967. Perceived risk and consumer decision making The case of telephone shopping. In D. F. Cox (Ed.), Risk taking and information handling in consumer behavior (pp. 487506). Boston: Harvard University.

Featherman, M.S., and P.A. Pavlou (2003). Predicting E-services adoption: A perceived risk facets perspective. International Journal of Human-Computer Studies, 59, (1), 51-74.

Fenech, T., and O'Cass, A., (2001). Internet users' adoption of Web retailing: User and product dimensions. Journal of Product and Brand Management, 10, (6), 361-381.

Forsythe, S.M., and Shi, B., (2003). Consumer patronage and risk perceptions in internet shopping. Journal of Business Research, 56, (1), 867-75.

Garner, S. J. (1986). Perceived Risk and Information Sources in Services Purchasing. The Mid-Atlantic Journal of Business, 24, (2), 49-58.

Gefen, D. (2003). TAM of just plain habit: A look at experienced online shoppers. Journal of End User Computing, 15, (3), 1-13.

Hamann, J. (2000). Virtual Villages: Bringing the Village Market to the Internet. Available at www.cnn.com (accessed February, 14, 2010).

http://www.citc.gov.sa/arabic/MediaCenter/Annualreport/Documents/PR_REP_005A.pdf

Jarvenpaa, S. L. and Todd, P. A., (1997). Consumer reactions to electronic shopping on the World Wide Web. International Journal of Electronic Commerce, 2, (2), 59-88.

Jarvenpaa, S. L. and Tractinsky, N. (1999). Consumer Trust in an Internet Store: A Cross-Cultural Validation. Journal of Computer-Mediated Communication, Vol. 5, No. 2. Available at: http://www.ascusc.org/jcmc/vol5/issue2/ jarvenpaa.html

Keen, C., Wetzels, M., Deruyterd, K. \& Feinburg, R. (2004). E-tailers versus retailers. Which factors determine consumer preferences. Journal of Business Research,. 57, (7), 685-695.

Kogan, N., and M.A. Wallach, (1964). Risk-taking: A study in cognition and personality. New York: Holt, Rhinehart \& Winston.

Levy, M. and Weitz, B. (2001), Retailing Management, McGraw-Hill, New York, NY.

Liao, Z. and Cheung, M.T. (2001). Internet-based e-shopping and consumer attitude: an empirical study. Information \& Management, 38, (2), 299-306.

O'Cass, A., and T. Fenech. (2003). Web retailing adoption: Exploring the nature of internet users web retailing behavior. Journal of Retailing and Consumer Services, 10, (2), 81-94.

Park, J., D. Lee, and J. Ahn (2004). Risk-focused e-commerce adoption model: A cross-country study. Journal of Global Information Technology Management, 7, (2), 6-30.

Pavlou, P.A. (2003). Consumer intentions to adopt electronic commerce - incorporating trust and risk in the technology acceptance model, International Journal of Electronic Commerce, 7, (3), 101-34.

Salisbury, W.D., Pearson, R.A., Pearson, A.W. and Miller, D.W., (2001). Perceived security and World Wide Web purchase intentions. Industrial Management and Data Systems, 101, (4), 165 - 177.

Shih, H.P., (2004). An empirical study on predicting user acceptance of e-shopping on the web. Information \& Management, 41, (3), 351-368.

Shim, S, Eastlick, M. A. \& Lotz, S., (2000). Assessing the impact of Internet shopping on store shopping among mall shoppers and Internet users. Journal of Shopping Centre Research, 7, (2), 7-43.

Sproles, G. B. \& Burns, L. D. (1994). Changing appearances. Understanding dress in contemporary society. Fairchild Publications. New York. 